\title{
Standpunt
}

\section{Toekomstige waterbenuttingsopsies vir Suid-Afrika}

Dit is welbekend dat Suidelike Afrika swak bedeel is met natuurlike waterbronne. As die hernubare varswaterbronne van elke land saam met bevolkings- en waterverbruikstoename in 'n sogenaamde waterskaarsheidsindeks gekombineer word,' word Suid-Afrika, Lesotho, Malawi, Mosambiek, Tanzanië en Zimbabwe as lande in Suidelike Afrika uitgewys wat teen 2025 ernstige waterstres of -tekorte in die gesig sal staar. In Suid-A frika word water wyd erken as die mees kritieke demper op die bevolkingsgrootte wat gehandhaaf kan word; tans geraam in die omgewing van 80 miljoen. Die Waterwet van 1956, ingevolge waarvan meeste van ons bestaande water-infrastruktuur neerslag gevind het, het hierdie probleem lank gelede voorsien en gevolglik die beginsel van indirekte hergebruik as uitgangspunt aanvaar. Hiervolgens mag 'n gebruiker slegs water uit 'n natuurlike loop onttrek met die uitdruklike voorwaarde dat die oorblywende water na gebruik weer teruggeplaas word in die loop waaruit dit onttrek is, nadat dit natuurlik tot 'n neergelegde minimum standaard gesuiwer is. Op hierdie manier word die water weer beskikbaar vir potensiële stroomafverbruikers. Die voordele van hierdie vorm van indirekte hergebruik is dat dit goedkoop is, dat dit die grondwater aanvul, dat dit die rivierekologie bevoordeel omdat dit 'n basisvloei selfs tydens droogtes verskaf, dat dit die selfsuiweringsvermoë van riviere benut, en dat die rioolwater se identiteit, uit die oogpunt van die stroomafverbruiker, verlore gaan.

Dit word egter toenemend duidelik, na volgehoue navorsing en ondervinding in Suid-Afrika en elders oor die afgelope veertig jaar, dat hierdie oënskynlik eenvoudige en elegante begrip van indirekte hergebruik 'n veelkantige vraagstuk geword het wat ernstig ontleed en selfs heroorweeg behoort te word. 'n Aantal redes hiervoor is:

- Namate relatief meer water vir stedelike gebruik aangewend word, word gesuiwerde rioolwater 'n groeiende komponent van ons riviervloei. Tydens droogteperiodes is die riviervloei dikwels reeds oorheersend gesuiwerde rioolwater. By die Rietvleidam in Pretoria, byvoorbeeld, maak gesuiwerde rioolwater van die Kemptonparkgebied in droogtetye meer as $80 \%$ van die riviervloei uit. Selfs in die waterryke VSA was daar volgens die United States Environmental Protection Agency (USEPA) ${ }^{2}$ twintig jaar gelede amper meer as $10 \%$ gesuiwerde rioolwater in 15 miljoen mense se drinkwaterbron; en tydens droogtes tot $100 \%$ in 4 miljoen mense se drinkwaterbron.

- Die groeiende gebruik van huishoudelike en nywerheidschemikalieë word direk weerspieël in die samestelling van rioolwater. Dit is veral by die breë groep organiese chemikalieë waar die knoop lê. Rioolwater is uiteraard ryk aan organiese materiaal, en alhoewel die meeste daarvan tydens rioolsuiwering verwyder word, kan minder as $15 \%$ van die oorblywende organiese besoedeling na presies geïdentifiseerde chemiese verbindings herlei word. Daar is 'n eksponensiële groei in die beskikbaarheid van nuwe chemikalieë, wat tot groter onsekerheid en waarskynlik ook meer probleemverbindings gaan lei.

- Een van die nuutste en potensieel ernstigste probleme op die horison is dat sommige verbindings die endokriene stelsels van mens en dier kan ontwrig. 'n Aantal onafhanklike studies het byvoorbeeld geslagsveranderings bevestig in vis wat in gesuiwerde rioolwater aangehou is. USEPA het sopas begin met 'n reusepoging om die meer as 15000 chemikalieè waarvan meer as 4,5 ton elk per jaar geproduseer word, te toets vir endokriene ontwrigting; 'n program wat tot vyf jaar kan duur. $^{3}$

- Siekteverwekkende mikro-organismes is besig om weer 'n prominente kopseer vir watervoorsieningsowerhede oor die hele wêreld te word. Sedert die begin van die eeu het die gebruik van kragtige oksidante soos chloor en osoon die vrees vir grootskaalse watergedraagde epidemies laat afneem, maar onlangse epidemies (soos byvoorbeeld die 400000 infeksies en 54 sterftes in 1993 in Milwaukee wat deur die parasietgenus Cryptosporidium veroorsaak is) en die verrassend algemene voorkoms van organismes wat deur beter mikrobiologiese ontledingsmetodes aan die kaak gestel word, wek opnuut kommer. Probleme word by 'n verskeidenheid soorte organismes teengekom, onder andere by die enteriese virusse (bv. Hepatitis A), parasitiese protosoa (bv. Cyclospora en Cryptosporidium), en patogene bakterieë (bv. Mycobacterium). ${ }^{4}$

- Die breë publiek het toenemende inspraak in beleid en tegnologieë wat omgewings- en drinkwaterkwaliteit raak; vraagstukke wat selde objektief en sonder emosie beoordeel word.

Een ooglopende manier om hierdie probleme te verlig, is om nie die gesuiwerde rioolwater summier in ' $\mathrm{n}$ rivier te stort nie, maar om dit binne die menslike gebruikskringloop te hou. Dit word reeds op 'n paar maniere gedoen:

- Direkte huishoudelike hergebruik is die direkte hergebruik van hoogs gesuiwerde rioolwater in 'n gemeenskap se drinkwatervoorraad (soos sedert 1968 in Windhoek gebruik word). Hierdie opsie se risiko word deur sommige gesaghebbendes ${ }^{5}$ laer geag as indirekte hergebruik, omdat beter beheer oor so 'n geslote stelsel moontlik is. Waar die herwonne rioolwater planmatig met water van die konvensionele bron vermeng word, word die risiko verder verlaag. In die geval van Windhoek byvoorbeeld, sal die hergebruiksfraksie nooit $35 \%$ oorskry nie, wat veel laer is as waaraan baie ander verbruikers in die geval van indirekte hergebruik blootgestel word. Ondanks hierdie oorwegings lyk dit nie waarskynlik dat hierdie hergebruikstoepassing vir eers veel veld in Suid-Afrika gaan wen nie, hoofsaaklik weens die hoë koste, die ongetoetsde plaaslike publieke mening, en die onsekerheid wat deur nuwe probleemverbindings geskep word.

- Direkte nie-huishoudelike hergebruik is die direkte aanwending van gesuiwerde rioolwater vir nie-huishoudelike gebruik, soos in nywerhede of in die landbou. Dit is die hergebruiksopsie wat tans die meeste veld wen; daar word tewens op die oomblik aan 'n paar sulke nuwe projekte in SuidA frika gewerk, soos byvoorbeeld in Durban en Richardsbaai. Plaaslike praktyke wat reeds goed gevestig is, is die gebruik van gesuiwerde rioolwater in die papierbedryf en vir die besproeiing van munisipale parke en gholfbane. Tans word egter minder as $3 \%$ van die gesuiwerde riooluitvloeisel op 
hierdie manier in Suid-Afrika herwin, teenoor die vergelykende syfer van $84 \%$ vir ' $n$ land soos Israel..$^{\circ}$ Daar is dus geweldige potensiaal vir toenemende hergebruik in hierdie kategorie.

- Grondwateraanvulling met gesuiwerde rioolwater of vloedwater is 'n opwindende moontlikheid wat oorsee een van die suksesvolste hergebruiksopsies is. In Suid-Afrika word die toepassingsmoontlikhede beperk deur die beperkte voorkoms van geskikte akwifere. In Atlantis, wat deur 'n uiters geskikte sand-akwifeer onderlê word, word die grondwater reeds vir verskeie jare op die manier aangevul, terwyl 'n loodsprojek in Windhoek die afgelope jaar aangedui het dat water op dié manier selfs in 'n minder geskikte akwifeer van gebreekte rots veel meer effektief as in oppervlaktedamme met hoë verdamping geberg kan word.

Dit is egter onafwendbaar dat daar steeds 'n betekenisvolle gedeelte van die gesuiwerde rioolwater in riviere afgelaat sal word - die gevestigde beginsel van indirekte hergebruik. Kan hierdie praktyk sonder meer in die toekoms voortgesit word? Die destydse aanname dat konvensioneel gesuiwerde rioolwater na storting in in rivier weer geskik sal wees vir konvensionele watersuiwering verder stroomaf, is beslis nie meer geldig nie. Daar moet toenemend duurder en beter watersuiweringsprosesse in hierdie gevalle voorsien word, soos byvoorbeeld by Hartbeespoort- en Vaalkopdam wat beide stroomaf van stedelike Gauteng geleë is. Bly die beleid soos dit nou is, sal die watervoorsieningsektor hulle moet staal vir veel hoër suiweringskoste. Word die probleem alternatiewelik opgelos deur veel strenger standaarde vir gesuiwerde rioolwater te stel, word die rioolsuiweringsektor met hierdie bykomende koste opgesaal. Al sou die koste vir die twee opsies nagenoeg dieselfde wees, is daar ander dwingende redes waarom laasgenoemde opsie gevolg behoort te word:

- 'n Geskatte 11 miljoen van Suid-Afrika se bevolking het in 1996 nog steeds hulle water direk en sonder suiwering uit riviere gekry; 'n aanleidende oorsaak tot die groot aandeel wat watergedraagde siektes tot die siekteprofiel in landelike gebiede het. $^{7}$

- Strenger uitvloeiselstandaarde sal die natuurlike wateromgewing en algemene rivierekologie bevoordeel, wat tans 'n hoë prioriteit op nasionale beleidsvlak is.

- Die universele strewe dat menslike aktiwiteite ook deur 'n 'omgewingsgewete' getemper behoort te word. Indien dit onprakties sou wees om die kwaliteit van rioolwater by die punt van storting te verbeter, rus daar minstens 'n onus op die besoedelaar om die stroomafverbruiker vir sy verhoogde watersuiweringskoste te kompenseer.

Hierdie is ' $n$ debat wat op die institusionele en politieke terrein gevoer sal moet word, en wat tans ook byvoorbeeld in die VSA aan die orde is. Die skrywer voorsien egter dat, vanweë die feit dat strenger Suid-Afrikaanse uitvloeiselstandaarde baie moeilik bevredig en nog moeiliker afgedwing kan word, duurder en meer gesofistikeerde watersuiweringsprosesse die mees waarskynlike antwoord vir veilige watervoorsiening in die toekoms gaan bied.

\section{J. HAARHOFF}

Departement Siviele en Stedelike Ingenieurswese, Randse Afrikaanse Universiteit

\section{Johannesburg}

Mei 1999

\section{LITERATUURVERWYSINGS}

1. Ohlsson, L. (1995). Water and Security in Southern Africa. Publications on Water Resources, No 1. Department for Natural Resources and the Environment, SIDA, Stockholm

2. USEPA. (1980). Wastewater in Receiving Waters at Water Supply Abstraction Points, EPA-600/2-80-044, U.S. Environmental Protection Agency, Cincinnati, Ohio.

3. Anonymous (1999). US to screen for endocrine disruption, Water Quality, International, January/February 1999

4. Friedman-lluffman, Debra. Rose, Joan. (1999). Emerging water-borne pathogens, Water Quality International, November/December 1998.

5. Kriel (1995). Die potensiele voordele van die herwinning en hergebruik van stedelike afvalwater, Joernaal van die Suid-Afrikaanse Instinum van Siviele Ingenieurs, Eerste kwartaal 1995.

6. Grobicki, A., Cohen. B. (1998). Water reclamation for direct re-use in urban and industrial applications in South A frica. and its projected impact upon water demand, Technical Report KV $18 / 99$ to the Water Research Commission, Pretoria.

7. Williams, R. (1996). Reclaimed Water Re-use in Residential and Commercial Situations. Report to Churchill Fellowship Trust.

\section{Etiese aspekte aangaande die aanmeldbaarheid van HIV/VIGS, asook die gebruik van entstowwe}

Sedert die begin van die HIV-pandemie het 15 miljoen mense alreeds aan VIGS* gesterf. Vyf-en-negentig persent van alle HIVinfeksies en sterftes het tot dusver in ontwikkelende lande plaasgevind. Sub-Sahara-Afrika is die episenter van die wèreldwye epidemie met Suid-A frika aan die voorpunt as die land met die vinnigste groeiende epidemie. Daar word bereken dat een

*III'-posith'thit veru'ys na in persoon wat deur die virus geinfekteer is, termyl ITGS verwys na die siektes wat ontwikkel in 'n HV'-positien'e pasiënt a.g.v. die immmunonderdrukkende effekte van die virus. VIGS onw wikkel gemiddeld 5 tor lo jaar na in IIIV-infeksie. uit elke agt volwasse Suid-Afrikaners HIV-positief is, en dat persone tussen die ouderdomme 14 en 15 jaar die hoogste risiko het om geïnfekteer te raak.

In die lig van die oorweldigende toename van die epidemie in ons land is dit belangrik om oor sekere etiese aspekte rakende HIV/ VIGS te besin, wat verreikende ekonomiese en sosiale implikasies inhou.

In April 1999 het die Minister van Gesondheid, dr. N. Zuma, in die Staatskoerant aangekondig dat die moontlikheid om VIGS 'n anonieme aanmeldbare siekte te maak, ondersoek word. Die redes 
wat gelei het tot die besluit is om inligting te versamel oor: die getal persone wat VIGS het; die totale getal sterftes a.g.v. VIGS; maniere waarop die siekte manifesteer; die verspreiding daarvan in die bevolking asook die risikofaktore betrokke. Die inligting wat so ingewin word, kan onder meer gebruik word om voorkoming en behandeling te beplan, en die verskaffing van medisyne asook die epidemie te monitor.

Die aanmelding van VIGS-gevalle is nie 'n unieke prosedure nie, en word sedert die tagtigerjare in verskeie ontwikkelde lande toegepas. In plaas van VIGS word HIV-positiwiteit sedertdien eerder in hierdie lande aanmeldbaar gemaak, deur 'n unieke nommer aan so 'n pasiënt toe te ken, of om die pasiënt se naam te gebruik. Sedert Januarie 1998 neem 31 state in die VSA deel aan die aanmelding van naamgebaseerde HIV-gevalle. Twee state (Maryland en Texas) het 'n nie-naamgebaseerde, uniekenommersisteem geimplementeer. Die nuutste toevoeging tot die lys is die staat Alberta, Kanada, waar HIV-positiwiteit vanaf I Mei 1999 'n aanmeldbare toestand geword het. Volgens laasgenoemde staat se Minister van Gesondheid, Halvar Jonson, is die stap geneem om te verseker dat HIV-pasiënte toepaslike berading asook vroeë toegang tot behandeling kry, veral swanger vroue waar mediese behandeling infeksie van die baba kan voorkom.

Die situasie in Suid-A frika is ongelukkig baie ver van die ideaal soos toegepas in die ontwikkelde lande. Ons is terdeë bewus van die swak aanmeldingsdiens van ander aanmeldbare siektes in die land (bv. hepatitis B-virusinfeksie, tuberkulose, sifilis, ens.). Die toevoeging van ' $n$ verdere infeksiesiekte op die lys sal die situasie eerder versleg a.g.v. die groot getal betrokke, en sal 'n geweldige administratiewe las op die sisteem plaas. 'n Finansiële toewysing sal vir hierdie doel gemaak moet word, om eerstens meer gesondheidspersoneel op te lei sodat ' $n$ hoë graad van aanmelding gehandhaaf kan word, en tweedens om 'n administratiewe stelsel daar te stel wat grootskaalse anonieme aanmelding kan hanteer deur 'n gekodeerde numeriese sisteem wat duplikasie sal uitskakel. Pasiënte wat aan VIGS-verwante infeksies sterf in gebiede waar HIV-antiliggaamtoetse nie beskikbaar is nie, sal tot onakkurate statistieke lei.

Indien só 'n sisteem ingestel word, sal die kwessie van VIGSaanmelding alreeds uitgedien wees a.g.v. veranderde terapeutiese opsies wat tans vir HIV-positiewe pasiënte beskikbaar is (swanger vroue). Deur slegs VIGS-gevalle aanmeldbaar te maak, word die statistiek beperk tot persone wat die siekte 5 tot 10 jaar gelede opgedoen het en dit weerspieël dus nie die huidige epidemiologiese status van die siekte nie.

Die aanmeldbaarheid van VIGS, gesien in die Suid-A frikaanse konteks, is dus nie aan te beveel nie. 'n Meer realistiese benadering sou wees om op 'n gereelde basis steek proewe te doen in spesifieke brandpuntareas en dit te gebruik om die impak van die siekte in hierdie gebiede of provinsies te bepaal. Die gesondheidsowerhede kan dan 'n HIV/VIGS-beleid daarstel of aanpas by die veranderende situasie.

Die gebruik van medikasie (anti-retrovirale/HIV-behandeling) in die behandeling van HIV-infeksie is vir ontwikkelende lande onbekostigbaar. 'n Uitsondering kan gemaak word in die gebruik van Zidovudine by HIV-positiewe swanger vroue om oordrag van die virus na hulle babas te voorkom. Vir die res van die geinfekteerdes is daar tans nie veel hoop nie. Enorme pogings word wêreldwyd aangewend om 'n entstof teen HIV te ontwikkel wat voorkomend sowel as terapeuties (vir die reeds geînfekteerdes) gebruik kan word.

Die doeltreffendheid van enige entstof hang eerstens af van die veiligheid daarvan, en tweedens van die vermoë om 'n gepaste immuunrespons uit te lok. Om hierdie aspekte te evalueer, is eksperimente op diere en mense vóór vrystelling noodsaaklik. Dit is ook die geval by HIV-entstowwe, maar a.g.v. die unieke eienskappe van die virus is baie mense besorg oor die veiligheid daarvan. Pasiënte wat ingeënt word, sal ook heelwaarskynlik HIVpositief toets, terwyl hulle nie deur die virus geïnfekteer is nie. Dit kan verdere etiese dilemmas tot gevolg hê en spesiale toetse sal gedoen moet word om te bewys dat die persoon nie geïnfekteer is nie.

Ten spyte van bogenoemde probleme is mens-biomediese eksperimente essensieel voordat enige potensiële HIV-entstof vrygestel sal kan word. Soos in die verlede sal sulke evaluasies plaasvind binne die gedragskode vir menslike eksperimente soos vervat in die Helsinki Deklarasie van 1964, en wat sedertdien vier maal gewysig is. In prinsiep word die fisiese en geestelike toestand van pasiënte daardeur beskerm, met die voorwaarde dat die geneesheer slegs in die pasiënt se belang sal optree. Die meeste diagnostiese, terapeutiese en voorkomende prosedures hou gevare of risiko's vir pasiënte in, maar mediese vooruitgang is slegs moontlik deur navorsing wat uiteindelik gedeeltelik op eksperimentering op mense berus.

Duidelike riglyne vir bromediese navorsing op mense is beskikbaar, en sal toegepas moet word in die geval van HIVentstofevaluasie, bv:

- dit moet gebaseer wees op voldoende eksperimentering, reeds afgehandel in die laboratorium en op proefdiere;

- die uitvoering en ontwerp van die eksperimentering moet duidelik geformuleer word en vir kommentaar voorgelê word aan 'n spesiaal aangestelde komitee onafhanklik van die ondersoeker of bekostiger;

- navorsing mag slegs deur 'n wetenskaplik gekwalifiseerde persoon onder leiding van 'n geneesheer uitgevoer word;

- voor eksperimentering moet die voorsiene risiko's en voordele duidelik uitgespel word (m.a.w. ingeligte toestemming moet deur die pasiënt verleen word);

- alle voorsorg moet getref word om die privaatheid van 'n persoon te respekteer en te beskerm;

- 'n persoon het die reg om enige tyd uit die studie te onttrek.

Indien hierdie riglyne nougeset gevolg word, is die kans dat 'n persoon fisies of geestelik benadeel sal word minimaal. 'n Mens moet dit ook sien teen die agtergrond van die HIV-epidemie deurdat 'n kans gebied word om die siekte en lyding van die mensdom te verlig.

\section{E. JANSE VAN RENSBURG}

Departement Geneeskundige Virologie, Universiteit van Stellenbosch

Posbus 19063

Tygerberg, 7505

Mei 1999 